\title{
INTERPRETAR ENSINANDO E ENSINAR INTERPRETANDO: POSIÇÕES ASSUMIDAS NO ATO INTERPRETATIVO EM CONTEXTO DE INCLUSÃO PARA SURDOS
}

\author{
Audrei Gesser* \\ Universidade Federal de Santa Catarina
}

\begin{abstract}
Resumo: O objetivo desse artigo é descrever algumas passagens da atuação do intérprete educacional no contexto de uma escola regular, mais especificamente do $7^{\circ}$ ano em que quatro alunos surdos estão incluídos, e que conta com a implementação de um projeto bilíngue. Partindo da premissa de que a situação inclusiva impõe aos intérpretes fazeres pedagógicos durante $o$ ato interpretativo, interessou observar, por um lado, as construções de espaços temporais na sala de aula que suscitam vínculos e parcerias entre intérprete e professor para além da mera interpretação instrumentalizada; e por outro, a configuração das tomadas de decisões durante $\mathrm{o}$ ato interpretativo a partir de um acontecimento didático versado pelo professor regente. A análise dos registros gerados indica que há um trânsito entre a "posição-intérprete" e a "posição-mestre", sendo esta última ativada pela vontade da intérprete de criar vínculos e conexões com os alunos surdos em seu processo de aprendizagem; e a primeira, como efeito próprio dos desafios individuais com os quais se depara cotidianamente, em termos linguísticos, cognitivos, físicos e referenciais.
\end{abstract}

Palavras-chave: Intérprete educacional. Escola inclusiva para surdos. Língua brasileira de sinais.

* Doutora em Linguística Aplicada pela Universidade Estadual de Campinas (Unicamp). Professora Adjunta no Departamento de Artes e Libras, no Centro de Comunicação e Expressão, no Curso Letras-Libras. Professora colaboradora nos Programas de Pós-Graduação em Estudos da Tradução e Linguística na Universidade Federal de Santa Catarina (USFC). Florianópolis, Santa Catarina, Brasil. Email: audrei.gesser@gmail.com 


\title{
INTERPRET TEACHING AND TEACH INTERPRETING: POSITIONS ASSUMED IN THE INTERPRETATIVE ACT IN MAINSTREAM CONTEXTS FOR DEAF PEOPLE
}

\begin{abstract}
The goal of this article is to present some descriptions about the educational interpreter performance in the context of a mainstream school, more specifically in the $7^{\text {th }}$ grade with four deaf students included, in which a bilingual project has being carried out. Relying on the assumption that inclusion forces interpreters to activate pedagogical practices during the interpretative act, this investigation payed attention to two phenomena: by one hand, the constructions of temporal spaces in the classroom that claim ties and partnerships between interpreters and teachers, beyond the technical interpretation itself. By the other hand, the configurations regarding interpretative decisions making emerged from pedagogical happenings. The data analysis indicates that there is a switch between the "interpreter-positon" and the "master-position", being the last activated by the interpreter inner desire in creating ties and connections with deaf students in their learning process; and the former position, as an effect of the interpreter's own challenges faced daily, in linguistic, cognitive, referential, and physical terms.
\end{abstract}

Keywords: Educational interpreter. Mainstream school for the deaf. Brazilian sign language.

\section{Introdução}

Travar discussões acerca da educação de surdos em nosso país sempre foi tema de muitas divergências teóricas e práticas. Duas perspectivas políticas, todavia, dão o tom para compreendermos a gênese do que se reflete nas interações e práticas no cotidiano escolar. De um lado, convivemos com a atual Política de Nacional de Educação Especial (BRASIL, 2008), que de modo mascarado imprime um valor instrumental e técnico à Libras, tomando-a como meio de facilitar a inclusão de pessoas surdas, mas sem enaltecer seu real protagonismo e importância na construção da educação para surdos. Por outro, destacamos a Lei 10.436/02, o Decreto 5.626/05 e a Declaração de Salamanca que reconhecem a Libras e a comunidade surda, os aspectos que diferenciam surdos e ouvintes, 
no âmbito da língua(gem), identidade e cultura de indivíduos surdos, afirmando seus direitos enquanto minoria linguística e social.

Ao se falar de escola inclusiva podemos ter diferentes reações, desde as mais negativas, oscilando entre um certo mal-estar, uma desconfiança de olhares e a impossibilidade de qualquer prática educativa para surdos nesse viés, até reações mais otimistas sobre a condição de integração das diferenças que ela promoveria. Mas, os questionamentos persistem: como é possível incluir em cenários totalmente despreparados, onde professores e alunos surdos devem conviver por decreto? Os primeiros, vítimas de uma formação insuficiente e desqualificação profissional; os segundos, vítimas da exclusão e das tentativas fracassadas ao longo dos tempos não somente na escola, mas na sociedade de um modo geral... Quais alternativas educativas para surdos inclusos são possíveis aí, e como gerenciá -las frente as demandas prementes e os desafios cotidianos que uma sala de aula para crianças e/ou adolescentes, por exemplo, requer?

Não é objetivo desse artigo discutir (ou defender) a inclusão para surdos em escolas regulares. O tema é bastante polêmico e suscita perguntas tão complexas quanto as próprias respostas. Mesmo porque, a meu ver, inesgotáveis e válidos são os argumentos dos defensores de escola para surdos, que, em sua maioria, rechaçam a inclusão. Então, o que se pretende nessa discussão, por ora, é descrever e partilhar ações que estão sendo postas em prática na política educacional que se instaurou. Trata-se de uma experiência observada no 7ำ ano em uma escola, situada em uma cidade do interior do estado de São Paulo, trazendo à tona as vivências e interações dos sujeitos nela inseridos, com um olhar atento para os fazeres dos intérpretes de Libras que ali atuam. A escolha desse cenário escolar, todavia, não foi aleatória. A escola, que é inclusiva, diferentemente de tantas outras espalhadas em nosso país, conta com uma equipe privilegiada, que desde de 2008 anos vem desenvolvendo um projeto bilíngue ${ }^{1}$, com diversas ações estratégicas já implantadas. Isto é, no cotidiano escolar há um trabalho e sensibilização com gestores, professores e intérpretes, para os surdos se sentirem atendidos em sua especificidade linguística e pedagógica. 
Com efeito, os professores regentes ouvintes acabam (re)conhecendo o impacto social e educativo desdobrados do projeto e, de algum modo, tem a oportunidade de construir outros olhares - mais positivos e desvinculados de crenças equivocadas - para o aluno surdo, a surdez e a língua de sinais (GESSER, 2009).

\section{O intérprete de língua de sinais no cenário educacional}

A transformação acentuada que passa a educação para surdos se tornou possível com o respaldo dos discursos presentes nas legislações (cf. mencionado acima), em que considera a "pessoa surda aquela que, por ter perda auditiva, compreende e interage com o mundo por meio de experiências visuais, manifestando sua cultura principalmente pelo uso da Língua Brasileira de Sinais - Libras" (Art. 2º, Decreto 5.626/05). Essa asserção, portanto, evoca o direito dos surdos à informação, à comunicação e à educação através da língua de sinais. Nesse sentido, a tradução e interpretação para a Libras vêm a ser um dos meios de se assegurar tais acessos por pessoas surdas que vivem em uma sociedade majoritariamente ouvinte, sobretudo no contexto educacional, no qual crianças, em processo de formação, passam boa parte de sua vida. Mas, quais os desafios de uma prática interpretativa para surdos no cenário da inclusão? Quais as parcerias e posições assumidas por professores e intérpretes, na cena educativa, ao mediarem o conhecimento para alunos surdos?

Essas indagações corroboram o que Lacerda $(2000 ; 2009)$ vem defendendo em suas pesquisas: inscreve-se nessa situação peculiar de inclusão a figura do intérprete educacional (IE). Este, diferentemente do intérprete generalista (ou até de outros contextos da interpretação comunitária, arriscaria dizer), atua, segundo a autora, como sujeito que participa do processo de ensino e aprendizagem do surdo, sobretudo porque a interpretação que se desenha no cenário escolar "vai além de fazer escolhas ativas sobre o que [se] deve traduzir, envolvendo também modos de tornar conteúdos 
acessíveis para o aluno" (LACERDA, 2009, p. 34). Essa asserção se respalda em preceitos Bakthinianos, em que Lacerda considera o ato interpretativo em língua de sinais na sala de aula como prática de construção de sentidos. Desse modo, "uma tradução correta do ponto de vista linguístico nem sempre é a melhor opção educacional para propiciar conhecimento" (LACERDA, 2009, p. 35).

Ao se pensar e defender a identidade e o fazer educacional do intérprete, a premissa é que o trabalho deve ser em equipe, isto é, em colaboração entre intérprete e professores: há que se planejar as aulas, conversar sobre os modos pedagógicos acessíveis para se ensinar o surdo, dialogar sobre as estratégias de ensino, selecionar materiais e suportes didáticos apropriados. Mesmo sendo uma prática pouco comum nas escolas (no sentido da parceria), essa atuação se impõe como necessária e urgente. Um professor ouvinte, por exemplo, ao falar para seus alunos ouvintes em uma língua compartilhada oral, não tem como separar de seu discurso pedagógico a linguagem didática da língua em si. O mesmo é verdadeiro também em relação ao intérprete: ao mediar conhecimento em Libras, ele precisa lançar mão de uma linguagem pedagógica surda possível de se fazer no repertório das línguas de sinais. E por que essa discussão é importante?

Igualmente às divergências que se figuram nos discursos em documentos legais e nos embates quanto à acepção do termo inclusão por diferentes estudiosos e educadores, a discussão sobre o intérprete educacional é também alvo de algumas polêmicas quando observada na prática. É recorrente observar duas típicas (e indesejáveis) situações: uma em que o intérprete se empossa da figura de docente de modo arbitrário e autoritário (como se fossem os "donos" do surdo), em que o professor regente ouvinte se exime de qualquer responsabilidade, relegando a ele (intérprete) toda a responsabilidade da aprendizagem do aluno; e noutro extremo, quando o intérprete compreende que sua atuação não deve extrapolar para o campo do pedagógico (e o professor se vê em apuros, atuando muitas vezes, como se o surdo não existisse, ou ainda, fazendo de conta que o surdo aprende tudo). Em ambas as situações, 
podem sobreporem-se ainda disputas de poder, e tanto professor e intérprete sentirem-se subjugados e impotentes nos fazeres do cotidiano escolar. Vejamos algumas vozes que emergem ao serem indagados:

"Eu dou minha aula normal, como se não tivesse surdo ali! A intérprete é quem resolve tudo!” (professor, 2015).

"Não adianta, eu conheço os surdos e a Libras, e por isso me sinto responsável pelo aprendizado deles. O professor não faz ideia de como o surdo aprende. Acaba que sobra tudo pra mim..." (intérprete, 2012).

"Eu entro, interpreto e vou embora! Não fico nessa de assumir o papel de professora de surdo não!" (intérprete, 2012).

"Tenho visto que alguns professores se sentem ameaçados com a minha presença, tipo: esse intérprete está me vigiando? O que ele está dizendo ali para o surdo? Mas com o tempo foi mudando... (intérprete, 2015).

"Outro dia passei por uma situação desagradável. O intérprete deu a entender que do jeito que eu estava ensinando não ia funcionar para o surdo. Na hora fiquei calada, mas, quem ele pensa que é para dizer como eu tenho que ensinar? (professora, 2014).

As falas acima são representativas quanto à angustia e o desconforto vivenciados nos processos educativos inclusivos. A quem dar razão, portanto? Os abismos presentes em sala de aula, não são somente da ordem da diferença linguística (embora desencadeados potencialmente por ela), mas também das condutas profissionais esperadas do que um professor e um intérprete supostamente devem fazer. A institucionalização de "papeis", nesse cenário, é perturbada. Também é o ato tradutório. Assim defendem Carvalho e Martins (2014, p. 51): o intérprete - se quiser "sobreviver" nesse campo de atuação que é a escola inclusiva - precisará assumir “posições de mestria". $\mathrm{O}$ ato tradutório em si tem que ser transgredido 
e passar a existir como "um necessário processo de ensinagem" e, "de TISLE (tradutor-intérprete de língua de sinais educacional), passa a ser um MISLE (mestre-intérprete de língua de sinais educacional $\left.^{2}\right)$ ". Paradoxalmente, entendem os autores, a inclusão viria a ser, então, um gatilho para a potência de se ensinar criativamente:

\begin{abstract}
Traduzir não é ensinar. Mas, à medida que o tradutor vê-se frente a frente com a tarefa de ensinar traduzindo e traduzir ensinando, ele, muito mais do que ensinar, ativa o efeito próprio da inclusão de possibilidades concretas circunscritas às experiências educativas. Dessa maneira, evitamos a dimensão quase ingênua de se pensar que traduzir já é incluir, o que não é verdadeiro, pois uma tradução pode muito bem cumprir o seu papel técnico, mas entrar em total deriva no sentido próprio de poder ensinar algo a alguém. (CARVALHO; MARTINS, 2014, p. 57).
\end{abstract}

Na problematização e reflexão dos autores, que segue o viés da filosofia francesa das diferenças a partir de Deleuze, Guattari e Foucault $^{3}$, o ato de interpretar na sala de aula inclusiva está "eivado de propriedade pedagógica”. Fica bem claro que a premissa dessa atuação interpretativa perpassa pela formação específica e pelas vivências práticas, e que "a necessidade do preparo de uma aula, por parte do TILSE, é da mesma ordem da demanda do professor regente" (CARVALHO; MARTINS, 2014, p. 60). Em um espaço discursivo como o da escola, esse preparo da aula conta não apenas com o domínio do conteúdo como também com habilidades para lidar com eventos comunicacionais-interativos nele imbricados: compreensão de enunciados, discussão de temas, aquisição de vocabulário e de conceitos, atividades de leitura e escrita, exercícios de fixação, explicação de fórmulas e resolução de problemas, revisão de conteúdo, correção, tira-dúvidas, etc.

Em resumo, a função do TILSE, sugerem Carvalho e Martins (2014, p. 53-54.), deve ser pensada em três vias inseparáveis: a primeira, de que o exercício de maestria é inevitável em contextos 
inclusivos de ensino onde há a figuração de interpretação para surdos; a segunda, refere-se à impossibilidade de aprendizagem se a tradução for praticada e reduzida a um "mero gestual padronizado ou estanque", desconsiderando-se envolvimento e contaminação de ordem didática "afecto-perceptorial" com a condição do outro, que é aprendiz e é surdo. O desafio está posto: a terceira via convocaria, então, o profissional intérprete para ir além de uma prática instrumentalizada de tradução, instigando-o "a ser criador de signos de aprendizagem concretos".

Corroborando a ideia de que a "posição mestre" assumida pelo intérprete é desejável (e inevitável, se se quer promover aprendizagens!), e que esse posicionamento, para ser ativado, se instaura nos momentos que ele (o intérprete) envolve-se com a condição de surdez e da necessidade de aprender do aluno surdo, cabe perguntar: Como se dão as construções de espaços temporais na sala de aula que suscitam vínculos e parcerias entre intérprete e professor para além da mera interpretação instrumentalizada ${ }^{4}$ de conteúdo? Em quais situações pedagógicas os repertórios do professor regente são (ou não) incorporados como mote de interpretação quando o intérprete se investe da posição-mestre? Ou seja, como se apresentam as tomadas de decisões durante o ato interpretativo a partir de um acontecimento didático?

Com o objetivo de se olhar algumas atuações em sala de aula, isto é, o fazer cotidiano de intérpretes e professores interagindo com alunos surdos e ouvintes, esta pesquisa contou com fundamentos da abordagem etnográfica de pesquisa (AGAR, 1980; ERICKSON, 1986). De acordo com Winkin (1998, p. 133), a etnografia é permeada por múltiplos desafios, e pode ser definida como:

uma arte e uma disciplina científica, que consistem em saber ver. Em seguida uma disciplina que exige saber estar com, com outros e consigo mesmo... . Enfim, é uma arte que exige que se saiba retraduzir para um público terceiro (terceiro em relação àquele que você estudou) e, portanto, que se saiba escrever [ênfase do autor]. 
Ao se utilizar de ferramentas da etnografia, o ponto inicial para se realizar a investigação é observando o cenário e os fazeres cotidianos dos participantes em ação. Deste modo, o corpus provém de pesquisa com observação-participante, e inclui, por exemplo, registros gerados (MASON, 1997) em forma de notas de campo, algumas gravações em áudio/vídeos, e conversas informais com os intérpretes e alguns professores. As próximas seções tratarão de fazer uma contextualização do cenário escolar, do projeto bilíngue que vem sendo implantado na escola, dos participantes, e das cenas de ensino observadas no $7^{\circ}$ ano, que conta com quatro alunos surdos incluídos.

\section{A escola, o projeto bilíngue e os participantes}

A escola, localizada no interior de São Paulo, é pública, mantida pelo município. Seu porte é pequeno, embora conte com um elevado grau de heterogeneidade do ponto de vista social, cultural, linguístico e econômico. Atualmente, há 17 alunos surdos matriculados na escola, 2 intérpretes, 1 professora de português para surdos, 1 professor surdo de Libras, e 3 professoras ouvintes bilíngues, 1 coordenadora escolar para os surdos, além dos professores ouvintes regentes que atuam nas salas regulares. Em termos estruturais, além das salas de aulas regulares da educação básica e da Educação de Jovens e Adultos (EJA), o espaço conta com uma sala utilizada para as aulas de português para alunos surdos e para reuniões e aulas de Libras para o grupo de famílias, e, também, uma sala multisseriada de instrução em Libras para crianças do ensino fundamental I - espaços criados a partir do projeto bilíngue.

Vale destacar que, em relação ao trabalho de formação com os intérpretes, reuniões são realizadas semanalmente no contra turno das aulas, e outros intérpretes convidados que atuam em outros cenários participam e enriquecem a discussão. Nesses encontros, temas como planejamento de aula e situações interpretativas vividas são partilhados. O objetivo, conforme o projeto, é o de acentuar “a 
questão das funções por eles assumidas, para além da tradução e interpretação dos enunciados dos professores" (SANTOS; DINIZ; LACERDA, no prelo). O mote das formações se pauta no fato de que os intérpretes deveriam se envolver nas práticas educacionais, de modo que dúvidas, sugestões e preparo das aulas em parceria com professores eram fortemente incentivados. O projeto teve seu início em 2008 e continuava em andamento no momento da realização dessa pesquisa, que ocorreu no primeiro semestre de 2015.

Neste estudo, optou-se por acompanhar a intérprete e os quatro surdos matriculados do $7^{\circ}$ ano matutino, nas disciplinas de Geografia, Artes, Matemática, Ciências e Inglês. Em uma ocasião, na disciplina de Inglês, ela foi substituída por outro intérprete que estava realizando seu estágio supervisionado (mas que também já havia atuado na escola e conhecia o projeto em questão). A intérprete, que vou chamar de Laura ${ }^{5}$, é formada em Letras-Português e tem especialização em Ensino, Tradução e Interpretação de Língua de Sinais, contando com 3 anos de experiência em interpretação para surdos no contexto educacional. Romeu, o intérprete que observei em duas situações, é licenciado em Inglês, e sua atuação como intérprete nas escolas é mais recente comparada com Laura.

Os quatro adolescentes surdos têm domínio na Libras, embora, observe-se variações de sinais durante o uso entre eles. Indiara, Fiorela e Márcio apresentam diferenças entre si quanto ao grau de surdez, à habilidade de leitura labial e oralização. Fernanda, por sua vez, é surda profunda e não é oralizada. Além disso, suas mães têm sido convidadas a participar de aulas de Libras ofertadas na escola para promover a construção de conceitos em Libras e ampliar o repertório comunicativo com implicações diretas para as interações em família, permitindo assim o estreitamento de laços afetivos via partilha de uma língua em comum com seus filhos. Embora os esforços da equipe em manter esses encontros sejam enormes, a frequência das mães é muito menor do que se gostaria. Fiorela e Márcio estudam na escola desde 2012, e Indiara e Fernanda desde 2014. Aparentemente, o grupo está adaptado na escola e tem um vínculo afetivo muito forte com a intérprete Laura. 


\section{Posições assumidas pelo intérprete educacional nas cenas de ensino}

O fato de realizar as observações em uma escola privilegiada - cujo grupo tem recebido assessoria de pesquisadores (orientações e formações) sobre a inclusão de surdos e sobre o projeto bilíngue pensado para fazer o acolhimento linguístico e pedagógico para professores, intérpretes, alunos surdos e familiares - capturou meu olhar para as posições encarnadas pelos intérpretes em ação, na condição de parceiro do professor regente. Isto é, a situação peculiar nessa escola é a de que o trabalho dos intérpretes em sala de aula é, de algum modo, reconhecido pela maioria dos professores como uma ação pedagógica.

Então, passei a observar como se davam algumas construções espaço-temporais na sala de aula que suscitavam vínculos e parcerias entre intérprete e professor para além da mera interpretação de conteúdo. Curiosamente, já nas primeiras observações da aula de Geografia, em que o professor regente inicia sua aula fazendo a correção de atividades sobre o tema abordado na aula anterior que versava sobre "trabalho e desemprego", a intérprete verifica se os alunos surdos realizaram a tarefa em seus cadernos. Enquanto o professor orienta os alunos ouvintes, Laura retoma o sinal da palavra "carteira de trabalho" e escreve no canto do quadro, repetindo o sinal em Libras. O aluno surdo Márcio, verifica se sua resposta contém essa palavra que é chave para o acerto da questão. De tempos em tempos durante a correção, o professor regente se certifica se está tudo certo por ali com os alunos surdos, perguntando à intérprete: "Tudo bem com eles aí, Laura? Eles fizeram a ativida$d e$ ?”. Laura informa que somente Indiara está tendo problemas, porque havia faltado a aula anterior, mas vai em direção a aluna e se engaja em breves explicações do tema. Neste mesmo instante, Márcio é chamado ao quadro pelo professor para responder uma das últimas questões, e levando o seu caderno com a resposta, faz a transposição escrita em português no quadro. O professor faz pequenas retomadas e acréscimos ao ler as respostas dos alunos, e 
nesses momentos, Laura se alinha ao discurso do professor, exceto quando da enunciação das palavras "Senai" e "CPF", quando interrompe o fluxo da interpretação para se certificar se os alunos surdos conhecem o sentido. A partir desse ponto, ao perceber as expressões faciais de dúvida dos alunos, a intérprete se descola da fala do professor e se embrenha numa outra avenida: a da explicação dos conceitos. Adiante, vê-se o professor anunciando para intérprete "Laura, quando precisar aí, chama ok? Qualquer coisa, dúvida, pergunta, acena!”

Outra situação bastante similar quanto à abertura que os professores dão à intérprete, com o objetivo de formar laços de parceria nas práticas educativas, foi observável em uma aula de Ciências. A professora pede aos alunos que escrevam um pequeno texto resumindo os temas estudados até aquele momento da disciplina, e não surpreendentemente, todos os alunos (surdos e ouvintes) sentem uma angústia diante da folha de papel em branco. Uma aluna ouvinte reclama da atividade, e logo vem um coro, ratificando a voz dela. A professora, então, rebate dizendo que todos têm que fazer porque ela decidiu que iria avaliar e dar nota. Impotentes diante do comando da professora, os alunos se põem a iniciar a atividade. Percebendo que a atividade causou dificuldades, a professora então faz pequenas retomadas, de tempos em tempos, dando pistas a todos os alunos sobre temas bem acessíveis e do cotidiano de todos. Laura, a intérprete, reforça as indicações da professora via interpretação, e vai além, retomando palavras-chave vinculadas com o assunto já estudado ("doença", "dengue", "bactéria", "higiene"). De início, os alunos surdos parecem não conseguir ativar seu conhecimento, a ponto de nem enunciarem-se em língua de sinais. A intérprete então sinaliza em tom jocoso: "cadê a memória? Tá vendo, não adianta só copiar, precisa entender, estudar!". Laura então, ao se colocar no lugar de aprendizagem do surdo (e percebendo também que os ouvintes estavam tão perdidos quanto), ativa a posição-mestre para "preencher essa lacuna didática”, empenhando-se na construção de sentidos. A professora se encaminha em direção aos surdos e sonda com Laura se eles estão 
conseguindo fazer a atividade. Somente Fernanda não conseguiu ir adiante com a explicação que ela havia oferecido segundos atrás e a professora então se engaja numa negociação com a intérprete, como que pedindo a sua chancela:

Professora: "Eu peço uma outra atividade para ela, então?" Laura: Pode sim, mas ela tava na aula, né? Ela deveria saber...

Professora: Ela lembra do sistema solar?

Laura: Sim, acho que lembra (olhando para a aluna surda pede que ela explique para a professora em Libras. Fernanda começa a sinalizar, e Laura vai interpretando a fala dela sobre a terra, o sol para a professora...)

Professora: Tá vendo? É isso mesmo, tá saindo... (percebendo que a aluna se refere aos movimentos de "rotação" e translação" na sinalização, que é interpretada por Laura em Português, a professora pede que a aluna faça a distinção entre os dois movimentos na sua atividade escrita. Fernanda, todavia, não reconhece a soletração das palavras "rotação" e translação", ficando na dúvida. A intérprete diz que ela que acabara de explicar o sentido em Libras, quando se dirigia a professora. Fernanda, surpresa, diz em Libras, "eu não conhecia as palavras, mas agora eu sei!").

Essa interação pode ser problematizada sob vários aspectos. No entanto, o que interessa, por ora, é enaltecer a busca de solução, mediada por uma aparente confiança por parte da professora, quando se informa com a intérprete que tipo de atividade poderia baixar a ansiedade dos surdos e alcançar o mesmo objetivo. Assim, os vínculos e parcerias entre a intérprete e os professores vão sendo formados, pouco a pouco. Tais enlaces, nas disciplinas observadas, se dão em momentos de adaptações e reconfigurações de atividades, quando o(a) professor(a) percebe o envolvimento e empenho na interação da intérprete com os surdos, ou como no último caso, quando ambas, finalmente se unem, para ativar o conhecimento 
prévio da aluna. A abertura entre professor, intérprete e alunos surdos para questionamentos e solução de dúvidas são relativamente garantidas nas cenas educativas, e quando os professores se "esquecem" que têm alunos surdos, e a intérprete tem dificuldades para prosseguir com interpretação-ensino, ela mesma solicita a participação e ajuda dos professores para sanar as lacunas de entendimento dos surdos ${ }^{6}$. $O$ ponto que prima pela parceria extraclasse, como elaboração de aulas em conjunto, todavia, Laura posteriormente me informou que era difícil acontecer, sobretudo pela dificuldade de conciliar os horários, e em casos mais extremos por falta de "vontade e interesse de alguns professores". Quando solicitava, a intérprete Laura conseguia a devolutiva dos professores sobre o conteúdo que iriam trabalhar, mas nenhum professor, entretanto, tinha o hábito de fazer esse movimento sem ser convocado.

Causou-me estranhamento, sobretudo na aula de Geografia, algumas situações de ensino paralelo sustentado pela intérprete. $\mathrm{Na}$ ocasião cheguei a ponderar se a posição-mestre da intérprete não estaria sendo demasiadamente assumida, a ponto de se ensurdecer diante das falas enunciadas pelo professor, ou mesmo negligenciá -las. Ilustrativo a esse respeito é a breve passagem:

O professor, ao ler uma resposta da atividade de um aluno sobre "captação lixo", faz complementações informativas, acrescentando curiosidades. Os alunos ouvintes estão engajados na escuta, e questões interessantes são levantadas por alguns deles como: a responsabilidade dos cidadãos em fazer reciclagem e coleta seletiva, os efeitos danosos para a natureza e para as pessoas, a falta de consciência das pessoas e carência em algumas regiões... Durante essa interação entre professor e alunos ouvintes, que leva alguns minutos recapitulando a atividade como um todo, a intérprete dedica-se a explicar o sentido da palavra "chorume", e em seguida cobra as respostas da atividade de cada um dos surdos, reafirmando a necessidade de se cumprir as tarefas (Notas de campo, 2015). 
A opção da intérprete em atuar de forma "independente" e descolada da enunciação do professor de Geografia nesse momento, ativando a posição-mestre para suprir outras necessidades, pode estar vinculada ao seu entendimento do que é prioritário naquele momento de desfecho da matéria, em função do contexto de ensino de outras aulas. Por isso, não se trata aqui de pleitear a ação puramente instrumental da intérprete (nem mesmo no sentido de se fidelizar todos os momentos de fala versados pelo professor), pois é certo que uma interpretação com boa fluência e boas técnicas interpretativas não garantem a construção de sentidos no processo de aprendizagem dos alunos surdos. Afinal, o processo de aprendizagem não pode ser facilmente escrutinado, e trata-se de um acontecimento: "nunca se sabe como uma pessoa aprende; mas de qualquer forma que aprenda, é sempre por intermédio de signos, perdendo tempo, e não pela assimilação de conteúdos objetivos" (DELEUZE, 2010, p. 21 apud CARVALHO; MARTINS, 2014, p. 58). O acontecimento seria então essa "tentativa de desnudar os sentidos que se inscrevem nas estruturas discursivas e que se atualizam em situações educativas presentes - atualização prenhe de memórias e de esquecimentos do estudante e do professor (SOUZA, 2007, p. 164).

Daí em diante, comecei a observar em quais situações pedagógicas os repertórios do professor regente estariam sendo (ou não) incorporados como mote de interpretação quando o intérprete se investe da posição-mestre e, com efeito, como se configurariam as tomadas de decisões, durante o ato interpretativo, a partir de um acontecimento didático. No contexto em tela, pode-se pontuar situações pedagógicas em que o intérprete ativa sua posição de mestria como recorrentes nos momentos das explicações e revisões de conteúdo, em que a intérprete acompanha o discurso do professor, mas se permite extrapolar, quando refina a linguagem didática para, como ela mesmo diz, "passar de um jeito que o surdo enten$d a$ ". Esse conduzir os discursos de modo a ensinar-interpretando é observável também em realizações de atividades e/ou exercícios em sala de aula, pois segundo Laura ela consegue ter mais liber- 
dade para atender os surdos, conforme as dúvidas individuais vão surgindo. Mas nessas mesmas situações, há desafios e desconfortos. Em conversa pessoal comentou que sempre há assuntos que os surdos têm mais dificuldade de compreendê-la e, quando isso acontece, ela afirma: "eles normalmente interrompem a tradução e me pedem definições, exemplos, e quando compreendem o significado, cada um deles quer compartilhar suas experiências sobre tal assunto, para demonstrar que entenderam”. Observando a atuação de Laura, é notório seu engajamento de congregação e atenção quando flagra dispersão ou incompreensão por parte dos alunos surdos, procurando saber se é por conta do conteúdo, da língua ou pela forma que ela está interpretando. Todavia, ao tomar a decisão de atender o aceno do surdo no meio do ato interpretativo, correm-se também alguns riscos. Voltemos à um episódio da aula de Ciências, que pode ser representativo no tocante à omissão de elementos no ato interpretativo:

Diante de algumas tentativas frustradas em fazer os alunos se debruçarem na atividade proposta (escrever sobre a matéria que tinham estudado até o momento), a professora resolve fazer um esquema no quadro, para ativar a memória dos alunos, assim intitulado: "Das células aos reinos dos seres vivos". Trata-se de uma revisão que suscita muita interação entre todos, pois a professora vai fazendo perguntas e dando pistas, e os alunos dando as respostas... Em um dado momento, surgem os conceitos de "eucariontes" e "procariontes", que são soletrados pela intérprete. A professora, então, escreve as duas palavras no quadro, e não somente retoma a definição, como recorre aos morfemas dos dois léxicos para fazer uma associação etimológica das palavras: "vocês sabem de onde vem esses nomes? A origem é grega: karyon significa núcleo, combinado com o prefixo pro-, que significa anterior. As células com um núcleo são chamadas eucariontes, onde o prefixo eu- significa bom ou verdadeiro". Para os surdos, entretanto, essa última parte é omitida... (Notas de campo, 2015). 
Não é nada fácil interpretar uma aula com léxicos e conceitos tão alheios do nosso uso cotidiano de linguagem. Sobretudo quando o processo de convenção de sinais é, muitas vezes, negociado, emergencialmente, no próprio curso da interação. Além disso, se já é complicado abordar etimologicamente o sentido de uma palavra falando em língua portuguesa para ouvintes adolescentes, o desafio é maior ainda quanto se tem que refinar essa ideia em Libras - o que exigiria da intérprete apontar para a nomenclatura escrita no quadro, soletrar as partes da palavra, remetendo a outra língua (o grego), e por fim, reconstruir todo o seu sentido em sinais, fazendo sentido, portanto, das partes no todo. A intérprete, ao tomar a arriscada decisão em não acompanhar o discurso da professora, omite conceitos daquele evento de explicação, que podem ter implicações futuras em termos de verificação de conteúdo (sobretudo, porque não são palavras comuns e de fácil memorização de sentido). Em conversa pessoal, Laura me informou que tem dificuldades em interpretar as aulas de História e Ciências, pois há o uso excessivo de metáforas e de jargões muito técnicos, requisitando muito soletramento manual: este último muito cansativo quando demasiadamente utilizado, e insuficiente para o surdo fazer sentido, no caso de nomes técnicos, se não for apresentada ou retomada uma definição (GESSER, 2009, p. 29). No caso de Ciências, Laura aponta que "a professora não usa de meios visuais para facilitar o aprendizado dos surdos" e isso dificultaria o trabalho dela ao interpretar suas aulas. Vejamos outras ocorrências na aula de Matemática:

Depois de realizar algumas correções das tarefas para casa, a professora faz um desfecho, retomando todos os cálculos aprendidos. Retoma as regras dos sinais (: $\left.x+-x^{2} \sqrt{ } 2\right)$. Escreve no quadro uma equação, e fazendo o uso de jargão matemático para resolução de problemas, vai obtendo o feedback e participação do grupo ouvinte. A professora, por sua vez, tem um razoável controle quanto a compreensão dos alunos ouvintes, mas em relação aos surdos, ela 
precisa se certificar a todo momento com a intérprete, convocando os alunos surdos a darem a resposta em alguns momentos. A expressão facial dos alunos surdos estampa incompreensão e dificuldade de acompanhar o processo de resolução do cálculo, e sempre que falham nas respostas, mas a professora insiste, para a explicação, dando-lhes tempo para pensar e responder (o que parece piorar ainda mais a situação, porque expõe o surdo num curso da interação partilhado "parcialmente"). Isto porque, na resolução da equação, noto que Laura deixou de interpretar boa parte do raciocínio lógico da professora regente, respondendo pequenas indagações pontuais que vão surgindo. A omissão na interpretação da fala da professora desemboca num equívoco, que é quando a professora pergunta a aluna surda Indiara, no desfecho do cálculo que vinha sendo realizado passo a passo, como ela chegou ao resultado 64. Somente esse momento é interpretado por Laura, porque a professora convoca a resposta da aluna, e ela responde incrédula à pergunta: "cheguei ao resultado porque fiz o exercício!" (Notas de campo, 2015).

Resposta viva, coerente. Ora, não há erro na resposta da aluna, mas sim equívoco na compreensão da pergunta; o sentido original se perde... E por que isso ocorre? $\mathrm{O}$ que a professora vinha fazendo, ao realizar a conta no quadro para todo o grupo, era tentar compreender a linha de raciocínio de cada aluno. E isso ficou claro a medida que as fases da equação iam sendo orquestradas verbalmente e concluídas. E ao perguntar para Indiara, já no desfecho do cálculo, o interesse da professora era saber se o raciocínio da aluna ao resolver " $(-16) .(-4)=64$ " se deu porque a aluna fez a multiplicação de $16 \times 4$, porque somou o número 16 quatro vezes, ou ainda ativou outro processo mental lógico. Isso foi indagado aos alunos ouvintes a cada fase da conta, e todos davam a sua versão quanto a linha de pensamento.

É fato que interpretar a linguagem matemática em Libras é um grande desafio: o linguajar numa conta de divisão ao enunciar, por 
exemplo, “quantas vezes 16 cabe dentro de 72?”, ou de multiplicação, “que número vezes que número dá 81?”. Portanto, como fazer sentido em Libras no momento em que a intérprete tem que fazer escolhas rápidas? Como (re)significar esses motes/jargões discursivos que se utilizam no ensino da Matemática? $\mathrm{O}$ fato é que no caso ilustrado, a omissão deliberada na interpretação da fala da professora regente durante o cálculo conjunto criou um abismo, abismo esse que teve implicações não apenas na falha de entendimento de Ingrid (como quem pensa: que tipo de pergunta é essa que a professora me faz?), mas sobretudo, com implicações sérias no que diz respeito a construção de raciocínio lógico e, com efeito, no processo de ensino e de aprendizagem.

\section{Considerações finais}

Ao reconhecermos o trânsito, do intérprete educacional, entre interpretar ensinando e ensinar interpretando, é possível inferir alguns impedimentos circunscritos no próprio desafio que é interpretar para surdos no contexto da inclusão. As tomadas de decisão dos intérpretes, de um modo geral, sobretudo quando interpretam de forma instrumental, podem estar condicionadas à: (1) falta de domínio e segurança no conteúdo; (2) falta de fluência linguística em alguns âmbitos discursivos; (3) dificuldades em se acompanhar a velocidade e as nuances do discurso oral na cena de instrução; (4) necessidade premente de se negociar sinais e conceitos com os alunos durante a interpretação; (5) participação desordenada e simultânea de vozes dos alunos surdos e ouvintes na interlocução com o professor; (6) coordenação de tantas informações diante do campo visual do surdo na cena didática (olhar para intérprete, quadro, caderno, professor, colegas ouvintes); (7) gerenciamento do contato visual dos alunos surdos para si e, com efeito, manter o interesse deles na aula; e (8) esgotamento físico e cognitivo.

Como foi assinalado, a situação inclusiva impõe aos intérpretes fazeres pedagógicos durante o ato interpretativo. O desdobramento 
dessa premissa, a partir do que foi observado nessa escola, aponta que, em determinadas cenas educativas, Laura transita entre a posição-intérprete e a posição-mestre, sendo esta última ativada por sua vontade de criar vínculos e conexões com os alunos surdos em seu processo de aprendizagem; e a primeira, como efeito próprio dos desafios individuais com os quais se depara cotidianamente: lidar com repertório linguístico da língua de sinais em constante construção; interpretar ininterruptamente e solitariamente; lidar com o desgaste físico e cognitivo; e, sobretudo, ter domínio de diversas áreas de conhecimento, seus jargões técnicos e idiossincrasias discursivas.

Oportuno retomar Carvalho e Martins (2014), neste ato de concluir, quando indagam: "até que ponto, neste caso, o TILSE pode falar daquilo que não sabe e pode ensinar aquilo que não domina?". A reflexão teórica respaldada nos dois autores que embasa a observação da prática em tela dos fazeres interpretativos observados em cenas cotidianas da escola reforça a necessidade de revermos a formação de intérpretes que atuam no contexto educacional, inclusive problematizando-se os efeitos do ato meramente instrumental da interpretação. Não se trata de responsabilizar o intérprete em todo o processo de formação educacional do surdo, ou de lhe computar funções para as quais não têm como ocupar sem apoio, estrutura, e parcerias, nem tampouco de se criar situações paralelas de ensino desconectadas do saber circulado pelo professor regente.

Trata-se de afinarmos urgentemente o discurso em relação as prioridades na formação de intérpretes educacionais e também de professores nas diversas licenciaturas, instaurando debates, convocando parcerias (GESSER, 2011). Pensarmos se não é o caso de fragmentarmos a formação e atuação do intérprete de língua de sinais por áreas de conhecimento, redefinindo e tendo bem claras as funções de todos os profissionais que atuam em contextos escolares inclusivos; buscarmos respaldos nas leis para pôr em prática - como por exemplo, no ato da criação de vagas em concursos destes profissionais - algo possível de se exigir no cotidiano escolar; problematizarmos as condições de trabalho e atentarmos para as armadilhas de interesses individuais ou de classe, melindrosamente 
arranjados nas políticas de educação e na relação oferta/demanda no mercado de trabalho. Esses podem ser alguns direcionamentos para darmos um passo adiante, não somente em relação à uma melhor compreensão da atuação do intérprete educacional, bem como, em relação à criação de melhores condições educacionais aos alunos surdos nas situações adversas da inclusão.

\section{Notas}

1. O projeto é coordenado pela Dra Cristina B. F. Lacerda, professora e pesquisadora da Universidade Federal de São Carlos (UFSCar), no Programa de Educação Especial, e conta com a participação de doutorandos e mestrandos, bem como a colaboração de outros profissionais da área da surdez do estado de São Paulo.

2. Na discussão os autores usam as duas formas - intérprete e tradutor - indistintamente, referindo-se às práticas interpretativas em sala de aula. Entretanto, a tradução e a interpretação são atividades distintas, cognitva e operacionalmente, que exigem competências específicas. Assim, nem todo intérprete é, necessariamente, um tradutor, nem todo tradutor um intérprete.

3. Os autores retomam discussões iniciadas em pesquisas anteriores. Mais detalhes ver Carvalho (2014) e Martins (2013).

4. Interpretação instrumentalizada no sentido da mera técnica, como ato interpretativo descolado de vínculos afetivos e sociais com a audiência.

5. Os nomes de todos os participantes foram alterados para resguardar a privacidade e confidencialidade dos mesmos.

6. Nessas duas situações não é possível afirmar até que ponto os alunos surdos aprenderam o que estava sendo abordado. Os registros gerados não são suficientes para fazer qualquer tipo de asserção nesse sentido. 


\section{Referências}

AGAR, M. The professional stranger. New York: Academic Press, 1980.

BRASIL. Política Nacional de Educação Especial na Perspectiva da Educação Inclusiva. MEC/SEESP, 2008. Disponível em: http://portal.mec.gov.br/seesp/ arquivos/pdf/politica.pdf >. Acesso em: abr. 2015.

CARVAlHO, A. F. de. Foucault e a Função-educador. 2. ed. Ijuí: Editora Unijuí, 2014.

CARVALHO, A. F. de; e MARTINS, V. R. de O. Posição-mestre e função-educador: relações ativas no ato da interpretação da língua brasileira de sinais em contexto de ensino. Políticas Educativas, Porto Alegre, vol. 7(2), pp. 51-70, 2014.

ERICKSON, F. Qualitative methods in research on teaching. In M. C. Wittrock (Org.), Handbook of research on teaching, pp. 77-200. New York: MacMillan, 1986.

GESSER, A. Libras? Que língua é essa? Crenças e preconceitos em torno da língua de sinais e da realidade surda. São Paulo: Parábola Editorial, 2009.

GESSER, A. Tradução e Interpretação da Libras II. Material didático desenvolvido para o curso Letras Libras na modalidade a distância. UFSC, 2011.

LACERDA, C. B. F. de. Intérprete de Libras: em atuação na educação infantil e no ensino fundamental. Porto Alegre: Mediação/FAPESP, 2009.

LACERDA, C. B. F. de. O intérprete de língua de sinais no contexto de uma sala de aula de alunos ouvintes: problematizando a questão. In: Lacerda, C. B. F. de e Góes, M. C. R. de (Org.). Surdez: processos educativos e subjetividade. São Paulo: Editora Lovise, 2000.

SANTOS, L. F., DINIZ, C. L. L. M., e LACERDA, C. B. F. de. Práticas de interpretação no espaço educacional: para além dos limites da sala de aula. In: 
Lacerda, C. B. F. de, Santos, L. F. e Martins, V. R. (Org.) Escola e diferença: caminhos para educação bilíngue de surdos. São Paulo: Fapeu. (no prelo).

MARTINS, V. R. de O. Posição-mestre: desdobramentos foucaultianos sobre a relação de ensino do intérprete de língua de sinais educacional. Tese (Doutorado em Educação) - Faculdade de Educação, Universidade Estadual de Campinas, Campinas/SP, 2013.

SOUZA, R. M. O professor intérprete de língua de sinais em sala de aula: ponto de partida para se repensar a relação ensino, sujeito e linguagem. ETD, vol. 8, 2007, pp. 154-170.

WINKIN, Y. A nova comunicação: da teoria ao trabalho de campo. Trad. Roberto Leal Ferreira. Campinas, SP: Papirus, 1998.

Recebido em: 15/07/2015

Aceito em: 29/09/2015 